\title{
УДК $550.83+552.5+553.98$ \\ ИНТЕНСИВНОСТИ ПРОЦЕССОВ НАЛОЖЕННОГО ЭПИГЕНЕЗА КАК ИНДИКАТОРЫ НЕФТЕНАСЫЩЕННОСТИ ПЕСЧАНЫХ КОЛЛЕКТОРОВ
}

\author{
Мельник Игорь Анатольевич, \\ migranis@mail.ru \\ Национальный исследовательский Томский политехнический университет, \\ Россия, 634050, г. Томск, пр. Ленина, 30.
}

\begin{abstract}
Актуальность исследования обусловлена возможностью выявлять пропущенные (низкоомные) продуктивные залежи в песчаных интервалах по материалам старого фонда геофизических исследований скважин (ГИС) и прежде всего там, где отсутствуют данные по керну.

Целью исследования является иллюстрация применения такого параметра, как интенсивность наложено-эпигенетических процессов в песчаниках в качестве индикатора нефтенасыщенности коллекторов на различных территориях Западной Сибири. объекты: верхне-среднеюрские песчаные отложения Томской области и ачимовская толща нижнемеловых песчаных отложений месторождения Самотлор.

В работе использована авторская технология статистической интерпретации данных ГИС на предмет выявления интенсивностей наложено-эпигенетических процессов каолинитизации, карбонатизации, пиритизации, пелитизации и пропущенных низкоомных УВ-насыщенных коллекторов.

Результаты. Подтверждено, что параметры интенсивностей наложено-эпигенетических процессов каолинитизации и пиритизации для юрских и меловых песчаных отложений различных территорий Западной Сибири могут служить индикаторами нефтенасыщенности коллекторов. Подобраны граничные значения индикаторов для Томской области и Самотлора. Парагенез наложено-эпигенетических процессов пиритизации и каолинитизации в песчаных интервалах указывает на их УВ насыщение. Эмпирические исследования показали, что коэффициент успешности применения данных индикаторов соответствует 75-80 \% при их определении инновационным методом статистической интерпретации ГИС для выявления пропущенных УВ залежей.

Вывод. Использование технологии статистической интерпретации данных ГИС с высокой степенью достоверности позволяет выявлять пропущенные нефтенасыщенные низкоомные интервалы на базе старого фонда материалов ГИС, а также решать литологические, петрофизические и геологические задачи (обусловленные глубинной флюидомиграцией) при поиске и разведке залежей нефти и газа.
\end{abstract}

\section{Ключевые слова:}

Наложено-эпигенетический процесс, вторичная каолинитизация, вторичная пиритизация, низкоомный коллектор, углеводороды, удельное электрическое сопротивление, геофизические исследования скважин.

\section{Введение}

Согласно определению, данному Б.А. Лебедевым, процесс наложенного эпигенеза - это геохимические и литолого-петрофизические изменения пород, вызываемые поступлением флюидов из внешних источников [1]. Эти изменения реализуются в результате поступления глубинных флюидов в коллектор по субвертикальным проницаемым зонам.

При изучении процессов наложенного эпигенеза в мезозойских отложениях Западной Сибири разные авторы сумели выделить группы аутигенных минералов в песчаных коллекторах в качестве индикаторов вертикальной флюидомиграции и нефтенасыщенности пород [2-9]. Например, формирования в песчаной породе вторичных карбонатов с кремнеземом, пелитизация и выщелачивание пород верхних интервалов исследуемого пласта определяют зону водонефтяного контакта [4-6]. Уменьшение интенсивности наложено-эпигенетических процессов (каолинитизации, карбонатизации и др.) в нефтенасыщенных коллекторах (вследствие «консервирующих» свойств углеводородов (УВ)) относительно интенсивности этих же процессов в водонасыщенных интервалах позволяет выделять перспективные пласты [8]. В зонах стабилизации водонефтяного контакта, при заполнении коллекторов УВ, зарубежные авторы выде- ляют подзоны выщелачивания, в которых происходят интенсивные растворения таких групп минералов, как полевые шпаты, кварц, карбонаты [10-18]. Как правило, все лито-геохимические аномалии локальны и территориально тяготеют к проницаемым зонам, глубинным разломам растяжения, формирующимся в результате тектонических движений земной коры [2-5, 7].

Лито-геохимические аномалии далеко не всегда генетически связаны с углеводородами. Поступления глубинных, химически агрессивных гидротерм могут привести к таким же результатам преобразования пород, что и при мигрирующей смеси УВ с органическими кислотами. Очевидно, что универсальным индикатором нефтенасыщенности различных территорий и горизонтов могут быть не столько группы вторичных минералов, а интенсивности преобразования аллотигенных минералов в данные группы. Причем аллотигенные минералы, содержащие в породах сравнительных залежей, должны быть сформированы в похожих фациальных обстановках осадконакоплений.

Целью данной работы является иллюстрация применения такого параметра как интенсивность наложено-эпигенетических процессов в песчаниках в качестве индикатора нефтенасыщенности коллекторов на различных территориях Западной Сибири. Рассмотрены геохимические процессы ка- 
олинитизации и пиритизации в песчаных породах нефтегазовых залежей Томской области и Самотлора. Проведен сравнительный анализ вероятностной связи данных процессов с УВ, возможности использования вычисляемых статистических параметров для поиска и разведки перспективных залежей разработанной технологией интерпретации материалов геофизических исследований скважин (ГИС).

В основном объектами исследований являются верхне-среднеюрские песчаные отложения Tомской области и ачимовская толща нижнемеловых песчаных отложений месторождения Самотлор. Причем корректность и валидность рассматриваемой инновационной технологии определения параметров статистических интенсивностей каолинитизации и пиритизации по данным ГИС в песчаниках исследована и подтверждена в ранних работах [19-22]. Например, доказано, что метод статистической интерпретации данных ГИС при вычислении интенсивности каолинитизации выявляет интервалы, содержащие только вторичные, аутигенные каолиниты.

Актуальность этой работы обусловлена появившейся возможностью выявлять пропущенные (низкоомные) продуктивные залежи в песчаных интервалах по материалам старого фонда ГИС и прежде всего там, где отсутствуют данные по керну. Низкоомные интервалы, как правило, возникают в результате образования поверхностной электрической цепи при интенсивной пиритизации и появления двойного электрического слоя в глинистых фракциях песчаных пород [23-25]. При традиционной интерпретации ГИС эти интервалы трактуются как водонасыщенные и пропускаются.

\section{Обоснование необходимости использования новых методов интерпретации ГИС}

Если эпигенетический процесс является причиной одновременного изменения двух (и более) исследуемых характеристик породы, то статистические параметры корреляционных зависимостей между выборками данных характеристик будут отражать влияния интенсивностей процессов на породу [19]. К таким параметрам относят коэффициент аппроксимации $\left(R^{2}\right)$ и интервальный параметр (Y). Произведение статистических параметров $i=Y R^{2}$ назовем статистической интенсивностью вторичных процессов, выражающее как качественную $\left(R^{2}\right)$, так и количественную $(Y)$ меры статистических регрессионных связей [19-22].

Вначале рассмотрим, в какой степени успешен традиционный метод интерпретации данных ГИС при поиске перспективных УВ насыщенных песчаных пластов в разведочных и поисковых скважинах Томской области. Для определения коэффициента успешности сделаем следующее допущение - пусть все испытанные песчаные интервалы изначально интерпретировались (стандартным способом) как перспективные нефтенасыщенные пласты.
Всего на таких участках и месторождениях УВ Томской области, как Болтная, Восток, Вертолетная, Киев-Ёганская, Мирная, Пинджинская, Снежная, Лесная, Рыбальная, Крыловская, Ясная и др., в 117 исследуемых скважинах были проведены испытания 269-ти песчаных интервалов мела и юры. Из них только 41 интервал оказался нефтенасыщенным, т. е. интервальный коэффициент успешности будет равен:

$$
K_{\text {инт }}=41 / 269=0,15 \text { д.ед. }
$$

Анализ данных скважин на предмет наличия в них УВ залежей определил коэффициент успешности, равный 0,25 , т. е. общий коэффициент успешности соответствует $3,7 \%$. Естественно, низкая величина этого коэффициента обусловлена не только введенным допущением, но и совокупностью неэффективных стандартных методик в определении места заложения скважин, основанных на выявлении антиклинальных ловушек при концепции органического генезиса УВ. На современном этапе развития геологической мысли перспективный участок с вероятным присутствием УВ залежи связывают не только с ловушкой (антиклинальной и неантиклинальной), но и с близкорасположенным вертикальным каналом миграции глубинных флюидов. Согласно неорганической концепции генезиса нефти, концентрация углеводородов в ловушках фундамента и мезозойских пород происходит вследствие глубинной миграции флюидов по ослабленным зонам нижних слоев литосферы и мантии [4, 26, 27].

Повышение интервального коэффициента успешности обычно связывают с переинтерпретацией материалов ГИС старого фонда на основе нестандартного подхода интерпретации ГИС либо на базе полученных новых данных исследуемой площади, их комплексирования. В результате исследований получают информацию о пропущенных перспективных нефтенасыщенных интервалах.

Из всех высоко-электропроводящих железосодержащих минералов в песчаных породах чаще всего встречается пирит. При незначительной минерализации пластовой воды (менее 35-40 г/л) обратная корреляция между удельным электрическим сопротивлением (УЭС) песчаной породы и относительным содержанием железа в большинстве своем обусловлена содержанием пирита. Пириты могут быть как аутигенными, т. е. обусловлены наложено-эпигенетическими процессами, так и аллотигенными, связанными с процессами осадконакопления. Многолетние исследования показали, что в нефтенасыщенных песчаниках интенсивность пиритизации в $95 \%$ случаев положительно коррелирует с коэффициентом трещиноватости пород, а при водонасыщенном коллекторе наблюдается отрицательная экспоненциальная регрессия [21]. Корреляционная связь интенсивности пиритизации с трещиноватостью пород является косвенным подтверждением причинно-следственной связи флюидодинамики с образованием пиритов, т. е. утверждает их вторичность. 
Возможно, что в процессе формирования залежи при фазовом разделении смеси воды и нефти происходит распад гидратной оболочки частиц «микронефти» на нефть и временно диссоциированную воду. Временно существующая гидроксильная группа идет на образование гидроксида железа, а избыток свободных ионов водорода приводит к уменьшению $\mathrm{pH}$ среды до 4-5. С присутствием сероводорода пиритизация будет проходить одностадийно, совместно с каолинитизацией породы, обуславливая их парагенез (рис. 2) [20-22, 28, 29].

\section{Анализ и обобщение результатов интерпретации данных ГИС}

Рассмотрим возможности применения технологии статистической интерпретации материалов ГИС старого фонда для повышения эффективности выявления нефтенасыщенных коллекторов в мезозойских отложениях. С этой целью была проведена статистическая интерпретация данных ГИС 20-25 песчаных интервалов в каждой из 117 скважин вышеперечисленных территорий Томской области. Проведено сопоставление величин интенсивностей пиритизации и каолинитизации в 269 испытанных пластах для нефтенасыщенных и водонасыщенных («сухих») интервалов (табл. 1).

Таблица 1. Усредненные результаты статистической интер претации ГИС для нефте- и водонасыщенных интер валов по Толской области

Table 1. Average results of well logging data interpretation in oiland water saturated intervals in Tomsk region

\begin{tabular}{|c|c|c|c|c|}
\hline \multirow[t]{2}{*}{$\begin{array}{l}\text { Насыщение } \\
\text { Saturation }\end{array}$} & $\mid \begin{array}{c}\left\langle i_{\text {пир }}\right\rangle \\
\text { Pyritisation } \\
\text { intensity }\end{array}$ & $\begin{array}{c}\left\langle i_{\text {каол }}\right\rangle \\
\text { Kaolinitization } \\
\text { intensity }\end{array}$ & $\begin{array}{c}I \\
\text { Total } \\
\text { intensity }\end{array}$ & $\begin{array}{c}Q \\
\text { Concealed } \\
\text { electrical } \\
\text { conductivity }\end{array}$ \\
\hline & \multicolumn{4}{|c|}{ усл. ед./conv. unit } \\
\hline $\begin{array}{c}\text { Нефть (H) } \\
\text { Oil (0) }\end{array}$ & 0,13 & 0,20 & 3,9 & 0,40 \\
\hline $\begin{array}{c}\text { Вода (В) } \\
\text { Water (W) }\end{array}$ & 0,11 & 0,16 & 3,0 & 0,33 \\
\hline $\mathrm{H} / \mathrm{B}(0 / \mathrm{W})$ & 1,18 & 1,25 & 1,3 & 1,23 \\
\hline
\end{tabular}

В табл. 1 даны усредненные интенсивности вторичных процессов пиритизации и каолинитизации для 41 нефтенасыщенных и 228 водонасыщенных испытанных интервалов. В четвертом и пятом столбцах показаны вычисленные статистические параметры. Эмпирическим путем определен параметр интенсивности, суммирующий рассматриваемые интенсивности, несущий наиболее отличительные признаки нефте- и водонасыщенных коллекторов:

$$
I=\exp \left(3\left(i_{\text {пир }}+i_{\text {каол }}\right)\right) \text {. }
$$

Отрицательная зависимость глинистости с УЭС обусловлена повышенной электрической проводимостью двойного электрического слоя (ДЭС) глинистой фракции. Зная статистические интенсивности рассматриваемых процессов (пиритизации, пелитизации и параметр ДЭС), определяющих поверхностную электрическую проводимость поро- ды, можно определить параметр скрытой электрической проводилости (СЭП) [22]:

$$
Q=\Sigma Y R_{i}^{2} \text {. }
$$

В четвертой строке табл. 1 даны отношения средних вычисляемых статистических параметров для нефтяных и водонасыщенных интервалов. Заметно, что величины всех "нефтяных" вычисляемых параметров на 20-30 \% больше «водных». Это является подтверждением связи исследуемых вторичных преобразований породы с углеводородами.

Рассмотрим возможности применения параметров I и $Q$ для выявления УВ насыщенных интервалов. Были использованы выборки нефтенасыщенных (41 шт.) и водонасыщенных (75 шт.) интервалов. Построены две гистограммы плотностей распределения параметра интенсивности, вычисляемые по формуле (1) (рис. 1). Анализ рис. 1 позволяет выбрать наиболее перспективные интервалы данного распределения с точки зрения повышенной вероятности выявления УВ насыщенных пластов. Граничные значения данных интервалов следующие: $I_{\text {д }}=[2,9-3,5]$ и $I_{\text {ув }}>7$ усл. ед.

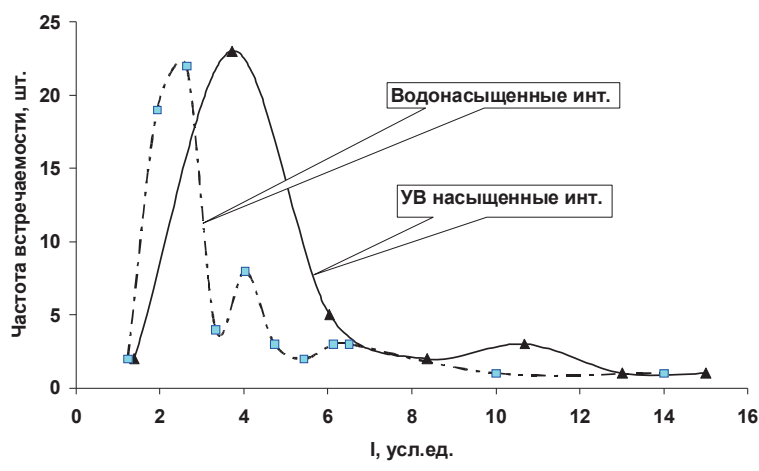

Рис. 1. Гистограмлы плотности распределения параметра интенсивности вторичных процессов в водо- и нефтенасыщенных песчаных интервалах мела и юры на месторождениях Томской области

Fig. 1. Density histograms show the intensity of secondary processes in water-and oil saturated sandstone intervals in Jurassic and Cretaceous deposits, Tomsk region

Определив граничные значения параметра $I$, был проведен анализ вероятности выявления нефтенасыщенных пластов в зоне границ $I_{\text {ув }}+I_{\text {Д }}$ из 269 интервалов. Из 41 УВ интервала в эту зону попало 13 интервалов при общем количестве 22 (УВ и водонасыщенных), что соответствует вероятности:

$$
P_{\text {инт }}=13 / 22=0,6 \text { д. ед. }
$$

Нас интересуют не просто нефтенасыщенные пласты, а пропущенные при стандартной интерпретации данных ГИС, низкоомные УВ насыщенные коллекторы. Поэтому мы вводим в выборочный анализ и параметр $Q(2)$, являющий показателем не только интенсивности вторичного преобразования, но и СЭП. При граничной величине $Q_{\text {гр }}>0,3$ и в зоне границ $I_{\mathrm{yв}}+I_{\text {д }}$ вероятность выявления нефтенасыщенных пластов (на территории Томской области из 269 испытанных интервалов) равна:

$$
P(Q)=11 / 14=0,78 \text { д. ед. }
$$


В этом случае в выборке осталось $27 \%$ от общего количества нефтенасыщенных коллекторов. Но зато коэффициент успешности в определении перспективных и рекомендованных к испытанию интервалов, в сравнении с традиционным методом интерпретации ГИС, увеличивается в 5 раз.

Итак, выбранные граничные величины параметров $I, Q$ являются критерием и индикатором нефтенасыщенности низкоомных (и не только) коллекторов для территории Томской области. Остается открытым вопрос о территориальной (по Западной Сибири) универсальности данных параметров. С целью ответа на поставленный вопрос проведем сравнение результатов "работы» рассматриваемых индикаторов по поиску УВ пластов на месторождении Самотлор с месторождениями Томской области.

На основе базы данных имеющейся выборки испытанных интервалов (40 нефтенасыщенных и 59 водонасыщенных пластов мезозойских отложений) месторождения Самотлор была проведена статистическая интерпретация материалов ГИС по представленным скважинам. На основании полученных результатов были вычислены средние значения рассматриваемых параметров (табл. 2).

Таблица 2. Усредненные результаты статистической интер претаци ГИС для нефте- иводонасыщенных интер валов по Самотлору

Table 2. Average results of well logging data interpretation in oiland water saturated intervals in Samotlor

\begin{tabular}{|c|c|c|c|c|}
\hline \multirow{2}{*}{$\begin{array}{c}\text { Hacыщение } \\
\text { Saturation }\end{array}$} & $\begin{array}{c}\left\langle i_{\text {пир }}\right\rangle \\
\text { Pyritisation } \\
\text { intensity }\end{array}$ & $\begin{array}{c}\left\langle i_{\text {каол }}\right\rangle \\
\text { Kaolinitization } \\
\text { intensity }\end{array}$ & $\begin{array}{c}I \\
\text { Total } \\
\text { intensity }\end{array}$ & $\begin{array}{c}Q \\
\text { Concealed } \\
\text { electrical } \\
\text { conductivity }\end{array}$ \\
\cline { 2 - 5 } & \multicolumn{4}{|c|}{ усл. ед./conv. unit } \\
\hline $\begin{array}{c}\text { Нефть (H) } \\
\text { Oil (0) }\end{array}$ & 0,126 & 0,11 & 2,78 & 0,40 \\
\hline $\begin{array}{c}\text { Вода (B) } \\
\text { Water (W) }\end{array}$ & 0,150 & 0,06 & 2,34 & 0,28 \\
\hline $\begin{array}{c}\text { H/B } \\
\text { (0/W) }\end{array}$ & 0,84 & 1,83 & 1,18 & 1,43 \\
\hline
\end{tabular}

Используя в качестве индикаторов «томские» параметры с оптимальными граничными величинами $I_{\text {гр }}>2,4, Q_{\text {гр }}>0,6$, мы получаем всего лишь $12 \%$ количество выборочных значений нефтенасыщенных коллекторов месторождения Самотлор с $80 \%$ достоверностью. Анализируя табл. 2 , можно отметить, что для повышения статистической значимости результатов исследований только интенсивность каолинитизации и параметр СЭП могут являться индикаторами УВ насыщения изучаемых интервалов. Поэтому в качестве индикаторов нефтенасыщенности для месторождения Самотлора принимаются данные параметры со следующими граничными величинами: $i_{\text {каол }}>0,13, Q_{\text {гр }}>0,4$. В этом случае в исследуемой выборке остается $\sim 27 \%$ от общего количества нефтенасыщенных коллекторов при вероятности, равной:

$$
P(Q)_{\text {инт }}=11 / 13=0,84 \text { д. ед. }
$$

Итак, согласно полученным результатам анализа статистических исследований можно сделать следующий вывод: для территорий с различной геологией необходимо эмпирическим путем подбирать не только величины граничных параметров, но и сами параметры-индикаторы УВ присутствия в исследуемых коллекторах. Только параметр СЭП универсален и может служить критерием нефтенасыщенности низкоомных интервалов.

По количеству нефтенасыщенных пластов в меловых отложениях, между Томской областью и Самотлором выявляется следующее различие - $5 \%$ по Томской области и $\sim 60 \%$ по Самотлору от общего количества мезозойских УВ пластов. Очевидно, этот факт обусловлен различием в величинах плотности разломов растяжения, секущих баженовскую свиту, являющуюся, в свою очередь, покрышкой для глубинных флюидов. На относительно небольшой территории Самотлора плотность каналов миграции в покрышке гораздо выше, чем на исследуемой территории Томской области [30, 31]. В этом случае усредненные интенсивности вторичных преобразований (обусловленные глубинными флюидами) будут больше на той территории, где плотность разломов покрышки меньше, т. е. в юрских отложениях Томской области. Это видно по результатам анализа табл. 1 и 2.

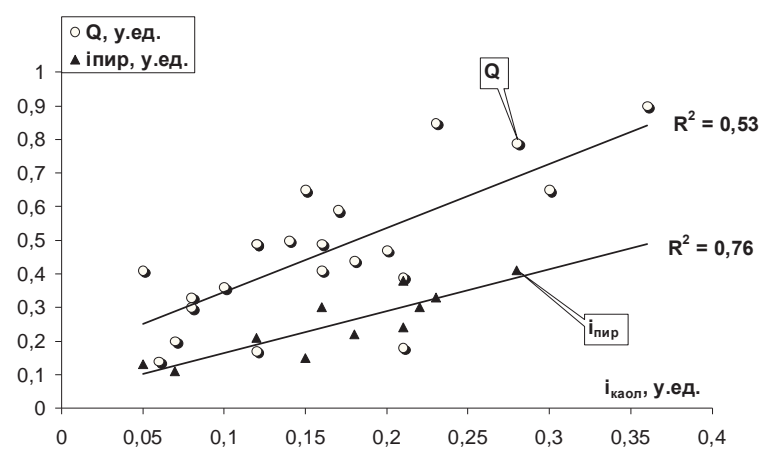

Рис. 2. Сопоставление интенсивности пиритизации и параметра СЭП с интенсивностью каолинитизации в нефтенасыщенных интервалах месторождения Самотлора. (Прим. СЭП (Q) - скрытая әлектрическая проводимость)

Fig. 2. Correlation between pyritization intensity, CEC parameter and kaolinitization intensity in oil saturated intervals of $\mathrm{Sa}$ motlor field. (Note. CEC $(Q)$ is the concealed electrical conductivity)

Еще одним важным отличительным признаком в нефтенасыщенных коллекторах месторождения Самотлор в сравнение с коллекторами Томской области будет различие причин «низкоомности». Многочисленные публикации различных авторов по Томской области подтверждают, что доминирующей причиной проявления УВ насыщенных низкоомных коллекторов являются содержащиеся в полимиктовых песчаниках пириты и вторичные глинистые минералы [23-25]. Доля интенсивностей вторичных процессов пиритизации и пелитизации будет представлять основной вклад в величину параметра СЭП. Как правило, эти минералы в песчаных породах формируются в резуль- 
тате поступления глубинных флюидов по фильтрационным каналам, образованным тектоническими процессами земной коры [4].

В отличие от Томской области, на территории Самотлора еще одной первопричиной «низкоомности» является фациальная (прибрежно-морская) обстановка осадконакопления. Прибрежно-морская обстановка седиментации формирует слоистую структуру по латерали с чередованием песчаных слоев с тонкими глинистыми прослоями [30]. Причем данные латерально протяженные прослои не выделяются на каротажных диаграммах вследствие их незначительных толщин, поэтому продуктивные пласты с низким удельным электрическим сопротивлением пропускаются. Электрическая проводимость пласта будет определяться её анизотропией, т. е. не только вертикальной, но и повышенной латеральной компонентами.

Корреляционный анализ вычисленных статистических параметров в нефтенасыщенных интервалах Самотлора позволил выявить две положительные регрессии интенсивности каолинитизации с интенсивностью пиритизации и параметром СЭП (рис. 2). На рис. 2 нулевые параметры не учитываются. В водонасыщенных пластах данные корреляции отсутствуют. Это подтверждает парагенетическую связь вторичных процессов каолинитизации и пиритизации с УВ. В свою очередь СЭП представляет собой аддитивную совокупность влияний на УЭС породы процессов пиритизации, пелитизации и образования ДЭС глин с повышенной электрической проводимостью. Анализ долевых величин показал, что основной вклад в долю СЭП в нефтенасыщенных пластах Самотлора оказывает ДЭС глинистой фракции, т. е. данный факт можно рассматривать как вторичное преобразование первичного (слоистого) глинистого цемента при каолинитизации полевых шпатов с последующей диффузией образованных катионов в ДЭС. В величине параметра СЭП доля пиритизации незначительная. Вследствие чего можно утверждать, что с ростом интенсивности каолинитизации повышается электрическая проводимость диффузионного слоя ДЭС, которая приводит к увеличению параметра СЭП.

\section{Заключение}

Проведенный анализ связей наложено-эпигенетических процессов с нефтенасыщенностью коллектора позволяет определить следующую закономерность - интенсивности вторичной пиритизации и каолинитизации могут служить индикаторами присутствия углеводородов в песчаных интервалах. Синхронность наложено-эпигенетических процессов пиритизации и каолинитизации в песчаных интервалах связана с нефтенасыщением. Для различных территорий с УВ залежами необходимо эмпирическим путем подбирать не только величины граничных параметров, но и сами параметры-индикаторы (вторичной пиритизации и каолинитизации) УВ присутствия в исследуемых коллекторах. Только параметр СЭП универсален и может служить критерием нефтенасыщенности низкоомных интервалов.

Эмпирические исследования показали, что по Томской области и Самотлору коэффициент успешности применения данных индикаторов для выявления УВ 80 \% при 27 \% количестве выделенных перспективных коллекторов от общего их числа.

Таким образом, использование технологии статистической интерпретации данных ГИС позволяет выявлять (с высокой степенью достоверности) пропущенные нефтенасыщенные низкоомные интервалы на базе старого фонда материалов ГИС.

\section{СПИСОК ЛИТЕРАТУРЫ}

1. Лебедев Б.А. Геохимия эпигенетических процессов в осадочных бассейнах. - Л.: Недра, 1992. - 239 с.

2. Природный тектонический насос углеводородов и вторичная доломитизация - порождение тектоно-гидротермальной активности рифтогенного осадочного бассейна / А.Д. Коробов, Л.А. Коробова, Е.Ф. Ахлестина, А.Т. Колотухин, В.М. Мухин // Известия Саратовского университета. Серия «Науки о Земле». - 2015. - Т. 15. - Вып. 3. - С. 46-52.

3. Роль дизъюнктивной тектоники в формировании пустотного пространства в коллекторах пласта $Ю_{1}{ }^{3}$ Западно-Моисеевского участка Двуреченского нефтяного месторождения (Томская область) / Н.М. Недоливко, А.В. Ежова, Т.Г. Перевертайло, Е.Д. Полумогина // Известия Томского политехнического университета. - 2005. - Т. 308. - № 5. - С. 47-53.

4. Предтеченская Е.А., Шиганова 0.В., Фомичев А.С. Катагенетические и гидрохимические аномалии в нижнесреднеюрских нефтегазоносных отложениях Западной Сибири как индикаторы флюидодинамических процессов в зонах дизъюнктивных нарушений // Литосфера. - 2009. - № 6. - С. 54-65.

5. Предтеченская А.Е. Минералогические аномалии как индикаторы процессов флюидомиграции в юрских нефтегазоносных отложениях Западно-Сибирской плиты // Осадочные бассей- ны, седиментационные и постседиментационные процессы в геологической истории: Материалы VII Всероссийского литологического совещания. - Новосибирск, 28-31 октября 2013. - Новосибирск: Институт Нефтегазовой геологии и геофизики имени академика А.А. Трофимука Сибирского отделения Российской академии наук, 2013. - С. 400-405.

6. Сахибгареев Р.С. Эпигенез юрских и меловых отложений центральной части Западно-Сибирской низменности // Советская геология. - 1970. - № 5. - С. 143-146.

7. Сердюк 3.Я., Слепокурова Л.Д. Геолого-геофизические аномалии и их роль при поисках неантиклинальных ловушек УВ в нефтегазоносных толщах Западной Сибири // Горно-геологическое образование в Сибири. 100 лет на службе науки и производства: Материалы международной научно-технической конференции. - Томск: Томский Государственный университет, 2001. - С. 243-246.

8. Чепиков К.Р., Ермолова Е.П., Орлова Н.А. Эпигенетические минералы как показатели времени прихода нефти в песчаные промышленные коллекторы // Докл. АН СССР. - 1959. T. 125. - № 5. - C. 1097-1099.

9. Геохимические критерии выявления коллекторов и прогноза их нефтегазоносности в терригенных отложениях Пур-Тазовской нефтегазоносной области / Е.Р. Исаева, В.Г. Ворошилов, 
Т.Ф. Тимкин, M. Ziaii // Известия Томского политехнического университета. Инжиниринг георесурсов. - 2018. - Т. 329. № 4. - C. 132-141.

10. Lasaga A.C. Chemical kinetics of water-rock interactions // J. Geophys. Res. - 1984. - V. 89. - P. 4009-4025.

11. Duan S., Wojtanowicz A.K. Theoretical and experimental investigation of water in oil transverse dispersion in porous media // SPE Annual Technical Conference and Exhibition. - Denver, Colorado, USA, 2008. - P. 1376-1401.

12. Alteration of crude oil by waters and bacteria; evidence from geochemical and isotope studies / N.J.L. Bailey, H.R. Krouse, C.R. Evans, M.A. Rogers // AAPG Bull. - 1973. - V. 57. P. $1276-1290$.

13. Velbel M.A. Influence of surface area, surface characteristics, and solution composition on feldspar weathering rates // Symposium Series: Geochemical Processes at Mineral Surfaces. - Chicago, Illinois, 1986. - № 323. - P. 614-634.

14. Worden R.H., Burley S.D. Sandstone diagenesis. Recent and Ancient. - USA: Blackwell Publishing company, 2003. - 647 p.

15. Worden R.H., Morad S. Clay Mineral Cements in Sandstones. USA: Blackwell Publ. company, 2003. - 503 p.

16. Bjorkum P.A., Gielsvik N. An isochemical model for formation of authigenic kaolinite, K-feldspar and illite in sediments // J. sedim. Petrol. - 1988. - V. 58. - P. 506-511.

17. Shengkai D., Wojtanowicz A.K. Hydrodynamic transition zone at OWC in non-Darcy flow // The second International Energy 2030 conference. - Abu Dhabi U.A.E., 2008. - P. 84-86.

18. Helgeson H.C., Owens C.E., Shock E.L. Petroleum, oil field waters, and authigenic mineral assemblages: are they in metastable equilibrium in hydrocarbon reservoirs? // Geochimica et Cosmochimica Acta, Abstr. - 1993. - V. 57. - P. 3295-3339.

19. Мельник И.А. Выявление вторично преобразованных терригенных коллекторов на основе статистической интерпретации материалов ГИС // Геофизика. - 2013. - № 4. - С. 29-36.

20. Мельник И.А. Латеральная миграция флюидов и интенсивность вторичной каолинизации в терригенных отложениях Томской области // Геология и минерально-сырьевые ресурсы Сибири. - 2016. - № 4 (28). - С. 9-14.

21. Мельник И.А. Интенсивность пиритизации как индикатор характера насыщения юрских пластов Томской области // Геология, геофизика и разработка нефтяных и газовых месторождений. -2016 . - № 3. - С. 41-49.
22. Мельник И.А. Определение интенсивности геохимических процессов по материалам геофизических исследований скважин. - Новосибирск: Сибирский научно-исследовательский институт геологии, геофизики и минерального сырья, 2016. $146 \mathrm{c.}$

23. Мельник И.А. Причины понижения электрического сопротивления в низкоомных коллекторах // Геофизические исследования. - 2014. - № 4. - С. 44-53.

24. Ежова А.В. Методика оценки нефтенасыщенности низкоомных коллекторов в юрских отложениях Юго-Востока ЗападноСибирской плиты // Известия Томского политехнического университета. - 2006. - Т. 309. - № 6. - С. 23-26.

25. Проблема выделения низкоомных коллекторов сложного строения юрских отложений Каймысовского свода / Ю.А. Чикишев, Н.П. Ковалева, В.А. Резниченко, Р.А. Шишкин // НТВ ОАО «НК «Роснефть». - 2008. - № 1. - С. 17-21.

26. Мельник И.А., Зимина С.В., Смирнова К.Ю. Нефтегазоносность территории Томской области как результат глубинной миграции // Геология, геофизика и разработка нефтяных и газовых месторождений. - 2017. - № 3. - С. 17-22.

27. Тимурзиев А.И. Современное состояние гипотезы осадочно-миграционного происхождения нефти (вопросы миграции УВ) // Геология, геофизика и разработка нефтяных и газовых месторождений. - 2009. - № 12. - С. 30-38.

28. Козеренко С.В., Храмов Д.А., Фадеев В.В. Исследование механизма образования пирита в водных растворах при низких температурах и давлениях // Геохимия. - 1995. - № 9. C. $1553-1565$.

29. Тараненко Е.И., Безбородов Р.С., Хакимов М.Ю. Преобразование коллекторов в нефтяных залежах // Геология нефти и га3а. - 2001. - № 2. - C. 18-22.

30. Геологическое моделирование прибрежно-морских отложений (на примере пласта AB1 (AB11+2+AB13) Самотлорского месторождения) / под ред. К.Е. Закревского. - Тюмень: Вектор Бук, 2017. - 314 c.

31. Конторович В.А. Тектоника и нефтегазоносность мезозойскокайнозойских отложений юго-восточных районов Западной Сибири. - Новосибирск: Изд-во СО РАН, филиал «ГЕО», 2002. $-253 \mathrm{c}$.

Поступила 03.04.2019 2.

\section{Информация об авторах}

Мельник И.А., доктор геолого-минералогических наук, профессор отделения нефтегазового дела Инженерной школы природных ресурсов Национального исследовательского Томского политехнического университета. 


\section{INTENSITIES OF SUPERIMPOSED EPIGENESIS AS INDICATORS OF OIL SATURATION IN SANDSTONE RESERVOIRS}

Igor A. Melnik,

migranis@mail.ru

National Research Tomsk Polytechnic University, 30, Lenin avenue, Tomsk, 634050, Russia.

The relevance of the research is caused by the possibility to identify missed (low-resistivity) productive reservoirs in sandstone intervals, based on the available well-logging data with the focus on the intervals with no core data.

The aim of the research is to apply the intensity of superimposed epigenetic processes in sandstones as an indicator of oil saturation in sandstone reservoirs in Western Siberia.

Objects: Upper Middle Jurassic sandstone deposits in Tomsk region and Achimov sequence of early Cretaceous sandstone deposits in Samotlor field.

Methods. A proprietary innovative statistical technique to interpret well-logging data is used to identify the intensities of superimposed epigenesist of kaolinitization, carbonatization, pyritization, pelitization and missed low-resistivity hydrocarbon-bearing reservoirs.

Results. It is proved that the intensity parameters of superimposed epigenesis of kaolinitization and pyritization for Jurassic and Cretaceous sand deposits in Western Siberia can be used as indicators of oil saturation in the reservoirs. The cutoff values for Tomsk region and Samotlor are identified. Paragenesis of superimposed epigenetic processes of pyritization and kaolinitization in sandstone intervals signifies hydrocarborn saturation of the intervals. Empirical evidence proves that the success rate of the applied indicators is 75-80\% if the indicators are estimated by the innovative statistical technique for well logging data interpretation.

Conclusion. The use of the innovative statistical technique for well logging data interpretation allows identifying missed oil-bearing lowresistivity intervals based on the well-logging data obtained earlier. It also enables solving lithological, petrophysical, and geological tasks (conditioned by deep fluid migration) while oil and gas prospects.

\section{Key words:}

Superimposed epigenetic process, secondary kaolinitization, secondary pyritization, low resistivity reservoir, hydrocarbons, specific electric resistivity, well logging.

\section{REFERENCES}

1. Lebedev B.A. Geokhimiya epigeneticheskikh protsessov v osadochnykh basseynakh [Geochemistry of epigenetic processes in sedimentary basin]. Leningrad, Nedra Publ., 1992. 239 p.

2. Korobov A.D., Korobova L.A., Akhlestina E.F., Kolotukhin A.T., Mukhin V.M. Prirodny tektonicheskiy nasos uglevodorodov i vtorichnaya dolomitizatsiya - porozhdenie tektono-gidrotermalnoy aktivnosti riftogennogo osadochnogo basseyna [Hydrocarbon natural tectonic Pump and secondary dolomitization as a Result of tectonic- hydrothermal Activity in a rift sedimentary Basin]. $I z$ vestiya of Saratov University. Earth science, 2015, vol. 15, Iss. 3, pp. $46-52$.

3. Nedolivko N.M., Ezhova A.V., Perevertaylo T.G., Polumogina E.D. Role of disjunctive tectonics in formation of voids in reservoirs, Layer $\mathrm{Yu}_{1}{ }^{3}$, Zapadno-Moiseevskiy site Dvurechenskoyr field (Tomskaya oblast). Bulletin of the Tomsk Polytechnic university, 2005, vol. 308, no. 5, pp. 47-53. In Rus.

4. Predtechenskaya E.A., Shiganova 0.V., Fomichev A.S. Katageneticheskie i gidrokhimicheskie anomalii v nizhnesredneyurskikh neftegazonosnykh otlozheniyakh Zapadnoy Sibiri kak indikatory flyuidodinamicheskikh protsessov v zonakh dizyunktivnykh narusheniy [Catagenetic and hydrochemical anomalies in LowerMiddle Jurassic oil-and-gas bearing deposits in West Siberia as indicators of fluid-dynamic processes in disjunctive dislocation zones]. Litosfera, 2009, no. 6, pp. 54-65.

5. Predtechenskaya A.E. Mineralogicheskie anomalii kak indikatory protsessov flyuidomigratsii v yurskikh neftegazonosnykh otlozheniyakh Zapadno-Sibirskoy plity [Mineralogical abnormalies as indicators of fluid migration in Jurassic oil bearing deposits of the Western Siberian plate]. Osadochnye basseyny, sedimentatsionnye i postsedimentatsionnye protsessy $v$ geologicheskoy istorii. Materialy VII Vserossiyskogo litologicheskogo soveshchaniya [Sedimentary basins, sedimentation and post-sedimentation in geo- logical history. Proc. of the VII All Russian lithological Conference]. Novosibirsk, 28-31 October, 2013. Novosibirsk, SB RAS Publ., 2013. pp. 400-405.

6. Sakhibgareev R.S. Epigenez yurskikh i melovykh otlozheniy tsentralnoy chasti Zapadno-Sibirskoy nizmennosti [Epigenesis of Jurassic and Cretacious deposits in central part of Western Siberian lowland]. Sovetskaya geologiya, 1970, no. 5, pp. 143-146.

7. Serdyuk Z.Ya., Slepokurova L.D. Geologo-geofizicheskie anomalii i ikh rol pri poiskakh neantiklinalnykh lovushek UV v neftegazonosnykh tolshchakh Zapadnoy Sibiri [Geophysical anomalies and their role in prospecting non-anticlinal hydrocarbon traps in oil-bearing formation]. Gorno-geologicheskoe obrazovanie v Sibiri. 100 let na sluzhbe nauki i proizvodstva. Materialy mezhdunarodnoy nauchno-prakticheskoy konferentsii [Geological and mining education in Western Siberia: 100 years on duty of science and industry. Proceedings of international scientific conference]. Tomsk, TSU Publ., 2001. pp. 243-246.

8. Chepikov K.R., Ermolova E.P., Orlova N.A. Epigeneticheskie mineraly kak pokazateli vremeni prikhoda nefti v peschanye promyshlennye kollektory [Epigenetic minerals as indicators of oil inflow time in production sandstone reservoirs]. Report $A S$ USSR, 1959, vol. 125, no. 5, pp. 1097-1099.

9. Isaeva E.R., Voroshilov V.G., Timkin T.F., Mansour Ziaii. Geochemical criteria to identify reservoirs and to forecast their oil and gas content in terrigenous deposits in Pur-Tazovskoy oilbearing field. Bulletin of the Tomsk Polytechnic University. Geo Assets Engineering, 2018, vol. 329, no. 4, pp. 132-141. In Rus.

10. Lasaga A.C. Chemical kinetics of water-rock interactions. J. Geophys. Res., 1984, vol. 89, pp. 4009-4025.

11. Duan S., Wojtanowicz A.K. Theoretical and experimental investigation of water in oil transverse dispersion in porous media. SPE Annual Technical Conference and Exhibition. Denver, Colorado, USA, 2008. pp. 1376-1401. 
12. Bailey N.J.L., Krouse H.R., Evans C.R., Rogers M.A. Alteration of crude oil by waters and bacteria; evidence from geochemical and isotope studies. AAPG Bull., 1973, vol. 57, pp. 1276-1290.

13. Velbel M.A. Influence of surface area, surface characteristics, and solution composition on feldspar weathering rates. Symposium Series: Geochemical Processes at Mineral Surfaces. Chicago, Illinois, 1986. No. 323, pp. 614-634.

14. Worden R.H., Burley S.D. Sandstone diagenesis. Recent and An cient. USA, Blackwell Publishing company, 2003. 647 p.

15. Worden R.H., Morad S. Clay Mineral Cements in Sandstones. USA, Blackwell Publ. company, 2003. 503 p.

16. Bjorkum P.A., Gielsvik N. An isochemical model for formation of authigenic kaolinite, K-feldspar and illite in sediments. J. sedim. Petrol., 1988, vol. 58, pp. 506-511.

17. Shengkai D., Wojtanowicz A.K. Hydrodynamic transition zone at OWC in non-Darcy flow. The second International Energy 2030 conference. Abu Dhabi U.A.E., 2008. pp. 84-86.

18. Helgeson H.C., Owens C.E., Shock E.L. Petroleum, oil field waters, and authigenic mineral assemblages: are they in metastable equilibrium in hydrocarbon reservoirs? Geochimica et Cosmochimica Acta, Abstr., 1993, vol. 57, pp. 3295-3339.

19. Melnik I. A. Vyyavlenie vtorichno preobrazovannykh terrigennykh kollektorov na osnove statisticheskoy interpretatsii materialov GIS [Identification of secondary converted terrigenous reservoirs based on the statistical interpretation data GIS]. Geofizika, 2013, no. 4, pp. 29-36.

20. Melnik I.A. Lateralnaya migratsiya flyuidov i intensivnost vtorichnoy kaolinizatsii v terrigennykh otlojeniyakh Tomskoy oblasti [Lateral migration of fluids and intensity of secondary kaolinisation in terrigenous deposits of the Tomsk region]. Geologiya mineralno-syrevye resursy Sibiri, 2016, no. 4 (28), pp. 9-14.

21. Melnik I.A. Intensivnost piritizatsii kak indikator kharaktera nasyshcheniya yurskikh plastov Tomskoy oblasti [Pyritization intensity as an indicator of the nature of the Jurassic formations saturation in Tomsk region]. Geologiya, geofizika i razrabotka neftyanykh i gazouykh mestorozhdeniy, 2016, no. 3, pp. 41-49.

22. Melnik I.A. Opredelenie intensiunosti geokhimicheskikh protsessou po materialam geofizicheskikh issledovaniy skvazhin [Evaluating intensity of geochemical processes by well-logging data]. Novosibirsk, Publ., SNIIGGiMS. 2016. 146 p.

23. Melnik I.A. Prichiny ponizheniya elektricheskogo soprotivleniya $\mathrm{v}$ nizkoomnykh kollektorakh [Causes of decrease in electrical resistance in low resistivity reservoirs]. Geofizicheskie issledovaniya, 2014, no. 4, pp. 44-53.

\section{Information about the authors}

Igor A. Melnik, Dr. Sc., professor, National Research Tomsk Polytechnic University.
24. Ezhova A.V. Method to evaluate oil saturation of low resistivity reservoirs in Jurassic deposits, the South-east of Westernsiberian plate. Bulletin of the Tomsk Polytechnic University, 2006, vol. 309, no. 6, pp. 23-26. In Rus.

25. Chikishev Yu.A., Kovaleva N.P., Reznichenko V.A., Shishkin R.A. Problema vydeleniya nizkoomnykh kollektorov slozhnogo stroeniya yurskikh otlozheniy Kaymysovskogo svoda [Identifying low resistivity reservoirs with complicated geological structure in Jurassic deposits of Kaymysovsky arch]. NTV $O A O \ll N K$ «Rosneft», 2008, no. 1, pp. 17-21.

26. Melnik I. A., Zimina S.V., Smirnova K.Yu. Neftegazonosnost territorii Tomskoy oblasti kak rezultat glubinnoy migratsii [Hydrocarbon potential of Tomsk region as a result of depth migration]. Geologiya, geofizika i razrabotka neftyanykh i gazovykh mestorozhdeniy, 2017, no. 3, pp. 17-22.

27. Timurziev A.I. Sovremennoe sostoyanie gipotezy osadochno-migratsionnogo proiskhozhdeniya nefti (voprosy migratsii UV) [Modern development of the hypothesis about sedimentary and migration oil formation (the issues of hydrocarbon migration)]. Geologiya, geofizika i razrabotka neftyanykh i gazovykh mestorozhdeniy, 2009, no. 12, pp. 30-38.

28. Kozerenko S.V., Khramov D.A., Fadeev V.V. Issledovanie mekhanizma obrazovaniya pirita v vodnykh rastvorakh pri nizkikh temperaturakh i davleniyakh [Studying pyritization in water solutions at low temperatures and pressures]. Geokhimiya, 1995, no. 9, pp. 1553-1565.

29. Taranenko E.I., Bezborodov R.S., Khakimov M.Yu. Preobrazovanie kollektorov v neftyanykh zalezhakh [Reservoir transformation in oil bearing formations]. Geologiya nefti i gaza, 2001, no. 2, pp. 18-22.

30. Geologicheskoe modelirovanie pribrezhno-morskikh otlozheniy ( $n$ a primere plasta AV1 (AV11+2+AV13) Samotlorskogo mestorozhdeniya) [Geological modelling of near shore-marine sediments (case study of AV1 (AV11+2+AV13) formation in Samotlor field]. Ed. by K.E. Zakrevsky. Tyumen, Vektor Buk Publ., 2017. 314 p.

31. Kontorovich V.A. Tektonika i neftegazonosnost mezozoysko-kaynozoyskikh otlozheniy yugo-vostochnykh rayonov Zapadnoy Sibiri [Tectonics and oil and gas potential of mesozoic-kainozoic deposits, South-eastern regions of Western Siberia]. Novosibirsk, SB RAS Publ., «GEO» branch, 2002. 253 p.

Received: 3 April 2019. 